\title{
Sensory quality of turnip greens and turnip tops grown in northwestern Spain
}

Marta Francisco $^{1}$, Pablo Velasco $^{1 *}$, Ángeles Romero ${ }^{2}$, Lourdes Vázquez ${ }^{2}$, María Elena Cartea $^{1}$

${ }^{1}$ Misión Biológica de Galicia (CSIC), PO Box 28, E-36080· Pontevedra, Spain

${ }^{2}$ Áreas de Nutrición y Bromatología y de Tecnología de Alimentos. Departamento de Química Analítica, Nutrición y Bromatología. Universidad de Santiago de Compostela. Facultad de Ciencias. Campus de Lugo. 27002 Lugo. Spain

*Corresponding author

Pablo Velasco

Address: Misión Biológica de Galicia (CSIC), PO Box 28, E-36080· Pontevedra, Spain

Tel: 0034-986854800

Fax: 0034-986841362

E-mail: pvelasco@mbg.cesga.es

\begin{abstract}
In Galicia (northwestern Spain), Brassica rapa var. rapa L. includes turnip greens and turnip tops as vegetable products. They are characterized by a particular sulfurous aroma, pungent flavor, and a bitter taste. In this work twelve local varieties grown as turnip greens and turnip tops were evaluated to define the sensory attributes, to relate them with secondary metabolites, and to select those sensorial traits that better describe these crops. Results showed differences in the sensory profiles of B. rapa varieties. Turnip greens were significantly differed for aroma intensity, leaf color, and salty taste, while turnip tops were for color and firmness of leaves, moistness and fibrosity in
\end{abstract}


mouth, sharpness, and bitter taste. Secondary metabolites as glucosinolates in turnip greens and phenolic compounds in turnip tops were highly correlated with texture and flavor. Glucosinolates especially progoitrin (in turnip greens) and gluconapin (in turnip tops) showed correlation with bitter taste and aftertaste persistence. Correlation between sensory traits showed highest values between leaf firmness and stalk firmness $(0.94 * *)$, leaf firmness and fibrosity $\left(\mathrm{R}=0.92^{* *}\right)$, aftertaste persistence and bitterness $\left(\mathrm{R}=0.91^{* *}\right)$ and between bitterness and moistness $\left(\mathrm{R}=-0.89^{* *}\right)$.

KEY WORDS: Brassica rapa, turnip greens, turnip tops, sensory quality, flavor. 


\section{Introduction}

B. rapa vegetable crops from Asian countries as Chinese cabbage, pak Choi or bock Choi have been extensively studied regarding different attributes (agronomic and nutritional) because of the importance of these crops in the Asian diet. Nevertheless, in Europe most research has been focused on different B. oleracea crops as cabbage, broccoli or cauliflower since these have a great economic importance in this continent and consequently, studies on nutritional quality of B. rapa types are minor. However, leafy forms of B. rapa crops are very popular in farming and diet in some European countries as Portugal [1], Spain [2] or Italy [3] where they are traditionally known as 'nabiças, or grelos' and cima di rapa or Italian turnip', respectively.

In Galicia (northwestern Spain), Brassica crops have been the main source of vegetables for human consumption and also for winter fresh fodder. According to the particularities of Galician agriculture (small familiar farms and traditional cultural practices), farmers obtain their own seeds for sowing. This process has led to a great number of Brassica landraces adapted to different conditions and to different uses all along Galician geography. In this region, Brassica rapa var. rapa L. includes turnip greens and turnip tops as vegetable products for culinary profit as well as turnips for fodder. Turnip greens are the young leaves, harvested in the vegetative period, wich are characterized by hairy lower leaves, petiolated with broad lateral lobes, which become larger at the top. Turnip tops are the fructiferous stems with the flower buds and the surrounding leaves. Upper flower spike leaves of an oblong spear shape, with two large rounded auricles, hairless and embracing the stem. The harvest of turnip tops occurs in late winter when the flower buds are formed, which are consumed before opening and while still green. Both are boiled and generally consumed as meat companions. They 
are characterized by a particular sulfurous aroma, pungent flavor, and a bitter taste, which differentiate them from other Brassica vegetables [4, 5].

Like all Brassica species, B. rapa crops contain secondary plant metabolites, mainly glucosinolates (which are found almost exclusively in Brassicaceae family) and phenolic compounds including flavonoids and hydroxycinnamic acids. The presence of these compounds in the diet has increased on the last years because of their beneficial health properties [6]. Moreover, these compounds have been related to the sensorial and nutritional qualities of vegetables. In fact, total glucosinolate content and their breakdown products were associated with sensory attributes in Brassica crops [7-9]. Other authors $[5,10]$ have reported that bitterness is considerably affected by the gluconapin, an aliphatic glucosinolate.

The cultivation of B. rapa takes place during the winter season. In many cases, the same variety can be exploited for several uses (turnips, turnip greens, and turnip tops), preventing the fixing of standard morphological characteristics and allowing the existence of local varieties with high levels of variability. A collection of 200 varieties collected from northwestern Spain was previously evaluated for their agronomic performance [2] as well as for their nutritional value focused on glucosinolate, fiber and protein content [5]. Besides, a first evaluation regarding sensorial attributes (bitterness and flavor) was carried out with the aim to discard those varieties that did not fit the normal parameters of this crop. As result, varieties were classified based on their morphological and agronomic attributes by using the Ward-MLM method [2]. Based on this previous classification, some varieties, suitable for turnip tops or/and for turnip greens fresh production were selected. Galician local varieties are maintained by local farmers based on their agronomic behavior but sensory quality was not a criterion to maintain them. 
In later years, the importance of the quality of vegetables for consumers has continuously increased. Main criteria are sensory characteristics and higher health benefits. Descriptive sensory analysis can be considered as the first step in the sensory characterization of a food product, providing a pre-defined terminology for describing sensory perceptions as objectively as possible [11]. Sensory profiles in Brassica crops have been determined mainly for $B$. oleracea crops such as Brussels sprouts, broccoli and cauliflower cultivars $[8,10,12,13,14]$. However, little information has been reported about descriptive sensory analysis for B. rapa crops as turnip tops and turnip greens. Only Jones \& Sanders [15] defined a panel based on flavor and aroma traits and found differences among turnip greens varieties and maturity.

The objectives of this study were i) to define the sensory attributes of a set of $B$. rapa varieties grown as turnip tops and turnip greens in NW Spain, ii) to relate them with the content of secondary metabolites and iii) to select those sensorial traits that better describe these crops .

\section{Material and Methods}

Plant material. Twelve local varieties of B. rapa were evaluated in this study (Table 1). From these, 10 varieties were chosen based on their agronomic performance for turnip tops and/or turnip greens and two varieties derived from three cycles of masal selection by fresh yield. The variety designation as well as their geographical and source of origin are shown in Table 1. The varieties were evaluated in two years (2006 and 2007) at two locations in northwestern Spain: Oroso (A Coruña) $\left(43^{\circ} 1^{\prime} \mathrm{N}, 8^{\circ} 26^{\prime} \mathrm{W}, 280\right.$ m.a.s.l.) and Guitiriz (Lugo) $\left(43^{\circ} 12^{\prime} \mathrm{N}, 7^{\circ} 53^{\prime} \mathrm{W}, 516\right.$ m.a.s.l.). Both locations represent standard $B$. rapa production areas in northwestern Spain. The varieties were planted in multiplot- 
trays and seedlings were transplanted into the field at the five or six leaves stage. Transplanting dates were on the $10^{\text {th }}$ and $19^{\text {th }}$ October in 2006 and on the $01^{\text {th }}$ and $04^{\text {th }}$ September in 2007, in Oroso and Guitiriz, respectively. Varieties were transplanting in a randomized complete block design with three replications. The experimental plots consisted of three rows with 10 plants per row. Rows were spaced $0.8 \mathrm{~m}$ apart and plants within rows $0.5 \mathrm{~m}$ apart. Transplanting was carried out manually according to local practice. A complex mineral fertilizer was added to the soil (8-15-15) at the rate of $412 \mathrm{Kg} / \mathrm{ha}\left(33 \mathrm{~K} / \mathrm{ha} \mathrm{N}, 62 \mathrm{Kg} / \mathrm{ha} \mathrm{P}_{2} \mathrm{O}_{5}\right.$ and $\left.\mathrm{K}_{2} \mathrm{O}\right)$. For pest control were used Aphox against aphids and Laidan against Delia radicum L . Force ${ }^{\circledR}$ was added at the time of transplantation against soil insects. Weed control were made according to local practices. Twenty five to forty leaves and shoots from each variety were harvested at each environment. Since trained panel must be done on several days, plant material (leaves and shoots) was sequentially harvested on each environment according to the maturity cycle of each variety at the optimum time for consumption. Leaf harvest ranged from 44 to 98 days after planting while shoot harvest ranged from 114-224 days after planting.

Sample preparation. Plant material was collected and immediately was carried to the laboratory for the sensory evaluation. The trained panel evaluation lasted several months as no more than three or four 4 varieties per day could be tasted. Samples were cleaned with water, selected and cut. After this, they were cooked in boiling water (no salt) for 45 minutes, with $1000 \mathrm{~W}$ heat-plates—in a $1100 \mathrm{~g}$ sample / $2 \mathrm{~L}$ water proportion. Once the samples were cooked, the excess water was drained off and servings of approximately $100 \mathrm{~g}$ were presented for each taster in plates coded with 3 random digits. The samples were distributed in a complete block design. Evaluation was 
performed in individual sensory booths with controlled humidity and temperature.

Sensory analysis. Descriptive sensory analyses were carried out according to AlonsoFernández et al. [16]. Thirteen trained panellists were selected for turnip greens and turnip tops sensory evaluation in accordance with [17]. Fifteen attributes were considered according to ISO norms [18]: aroma intensity, leaf color, leaf brightness, stalk and leaf firmness, resistance to cutting, moistness and fibrosity in mouth, sharpness, sticks to palate, bitter, acid sweet and salty taste, aftertaste persistence, and abnormal aroma. All descriptors were quantified using $10-\mathrm{cm}$ no structured intensity scales [19], except abnormal aroma which were evaluated on two-point scales. Reference values for each attribute are shown in Table 2. In all cases a rating of 1 was considered 'slight' and a rating of 10 as 'high'.

Statistical analyses. A combined analysis of variance across environments was performed for each sensory trait. Analysis were made independently for each of the two plant organs evaluated (leaves and shoots). Varieties were considered as fixed effects and environments were considered as random factors. Comparison of means among varieties was made by Fisher's protected least significant difference (LSD) at $P=0.05$ [20]. Simple correlation coefficients $(\mathrm{p}<0.05)$ among sensory traits were made in order to determine which traits better explain the sensory attributes of turnip tops and turnip greens. Total and individual glucosinolate content and total and individual phenolic compound content were quantified in the same set of varieties. Part of these results was published by Francisco et al. [21]. Therefore, simple correlations $(\mathrm{p}<0.05)$ between these secondary metabolites and sensory characteristics were made in order to establish the relationships between them. All statistical analyses were made using SAS [22]. 


\section{Results and Discussion}

\section{Turnip greens}

The combined analysis of variance showed significant differences for most traits (aroma intensity, stalk and leaf firmness, resistance to cutting, moistness and fibrosity in mouth, sharpness, sticks to palate, and bitter, acid, sweet and salty tastes) among environments (Table 3). Climatic conditions all along the crop cycle (between September 2006 and May 2008) were very different in each environment, being the minimum temperatures and the precipitation between the years 2007 and 2008 the main factors that considerably affected the sensory attributes , mainly for turnip greens (Fig.1). Varieties were very similar for most traits and they only significantly differed for aroma intensity, leaf color, and salty taste. The analysis of variance for sensory traits showed a significant environment $\times$ variety interaction for leaf brightness, resistance to cutting and sharpness (Table 3). For these three traits, individual analyses of variance were performed and varieties did not showed significant differences among them. Regarding variety performance across environments, 'MBG-BRS0461'showed the highest aroma intensity and the lowest leaf color and salted taste. By the other side, 'MBG-BRS0163' showed high salted taste, the lowest aroma intensity and the highest leaf color (Table 4). A descriptive profile graphic of the twelve varieties in turnip greens and turnip tops is shown in Figure 2.

Glucosinolates and phenolic compounds are secondary metabolites found in large quantities in B. rapa and responsible, among other roles, for the typical bitter taste and characteristic aroma of Brassica crops. The correlations between sensory traits with the content of aliphatic, indolic, aromatic and total glucosinolate content as well as the 
correlations between sensory traits with the content of phenolic compounds are showed in Table 6. Data show that most correlations between glucosinolates and sensory traits were low and non significant. The most remarkable was the negative relationship between progoitrin with bitter and salty taste, aftertaste presistance, and stick to palate ($0.69^{* *},-0.60^{* *},-0.74^{* *}$, and $\left.-0.79^{* *}\right)$. Walters [23] found a very closely relationship between bitter and sweet taste, which could be explained the negative values found in our work for bitter or salty taste. Progoitrin is not the main glucosinolate found in leaves of turnip greens but it has been often shown to be related to bitterness and taste preference in Brussels sprouts $[8,12]$. Progoitrin has been defined as a non-bitter glucosinolate. However, it can be degraded enzymatically by the enzyme thioglucosidase or by heat treatment to the extremely bitter compound goitrin [8].

The concentration of chlorogenic and sinapic acids affects considerably the sensory quality of food, since they contribute to enzymatic browning of food products, thus inducing their astringency and bitter taste [24]. Hydroxycinnamic acids are present in high amounts in turnip greens. However, as far as we know, information about the relationship between sensory traits characteristics of this crop such as bitterness, aroma or taste with flavonoids and hydroxycinnamic acids is lacking. Thus, this work means a real improvement in the study of nutritional quality of this crop. Some sensory traits evaluated in turnip greens seem to have important relationships with some phenolic compounds. For instance, moistness had positive and high correlations with total phenolic compound content $\left(\mathrm{R}=0.75^{* *}\right)$ and with total hydroxycinnamic acids $(\mathrm{R}=$ $0.74^{* *}$ ) whereas stalk firmness had positive and high correlations with hydroxycinnamic acids $\left(\mathrm{R}=0.85^{* *}\right)$. Even if glucosinolates and flavonoids are not structural compounds of the plant, it seems that there are a kind of relationship among plant structure and these compounds, which could be related to the plant health status 
and the roles of flavonoids and glucosinolates such as provide protection against ultraviolet radiation, pathogens and insect attack. All traits related to flavor (except sweetness) showed negative and significant correlation coefficients with total hydroxycinnamic acids and total phenolic compound content (ranging from $\mathrm{R}=-0.58^{*}$ to $\left.\mathrm{R}=-0.82^{* *}\right)$. Total flavonoids only showed a significant and moderate relationship with acid taste. Most of the literature related flavonoids with bitter, acid or astringent tastes [25] but minor alterations in the flavonol structure can change their taste from bitter to sweet or the other way around [26].

As summary, sensory traits evaluated in turnip greens seem to be more related to hydroxycinnamic acids and flavonoid compounds than to glucosinolates.

Hydroxycinnamic acids and total phenolic compound content were positively related to firmness traits and negatively related to flavor traits.

\section{Turnip tops}

Likewise happened for turnip greens, there were significant differences among environments for most traits, highlighting the importance of climatic conditions upon the sensorial quality of these crops. Thus, the choice of a particular variety in basis of its sensorial value should be done on many sites and years. The combined analysis of variance did not show any significant environment $\times$ variety interaction, which means the stability of different genotypes. Varieties were significantly different for color and firmness of leaves, moistness and fibrosity in mouth, sharpness, and bitter taste. Because of this variability, it would be possible to select in the future a particular variety according to consumer preferences. As well occurring in turnip greens, 'MBGBRS0163' displayed the highest leaf color. Besides, this variety had the lowest leaf firmness, fibrosity in mouth, stalk firmness and resistance to cutting even though no 
differences for these last two traits were found among varieties. 'MBG-BRS0143' had the lowest leaf color and the highest fibrosity in mouth. With regard to the bitter taste typical of this crop, the variety 'MBG-BRS0197' was the bitterest whereas 'MBGBRS0472' was the less bitter (Table 5). Although bitterness are usually considered as an unfavourable flavor trait, a certain degree of bitterness is appreciated by consumers because of it is a typical characteristic of this vegetables.

Correlations between glucosinolates and phenolic compounds were also calculated for turnip tops (Table 6). In contrast to happened in turnip greens, sensory traits evaluated in turnip tops seem to be more related to glucosinolates than to phenolic compounds. Total glucosinolate concentration in turnip tops $\left(25.6 \mu \mathrm{m} \mathrm{g}^{-1}\right)$ was higher than in turnip greens $\left(17.6 \mu \mathrm{m} \mathrm{g}^{-1}\right)$. This difference was due to aliphatic glucosinolates (20.6 $\mu \mathrm{m} \mathrm{g}^{-1}$ and $12.8 \mu \mathrm{m} \mathrm{g}^{-1}$, respectively), which can explain the higher importance of glucosinolates on the sensory traits of turnip tops. Likewise it was discussed for turnip greens, information about the relationship between sensory traits and glucosinolate and flavonoids content on turnip tops is scarce. Our study proves that some traits defining the texture and taste were related to glucosinolate content. For example, leaf and stalk firmness and resistance to cutting had negative, significant and moderate to high correlations (ranging from $\mathrm{R}=-0.58 *$ to $\mathrm{R}=-0.88 * *$ ) with indolic glucosinolate content and with the aromatic glucosinolate GST. On the other hand, bitter taste, acid taste, and aftertaste showed moderate correlations (from $\mathrm{R}=0.61 *$ to $\mathrm{R}=0.74 * *$ ) with indolic, aliphatic, aromatic and total glucosinolate content. Regarding individual glucosinolate composition, gluconapin (the major glucosinolate in these crops) showed positive and significant correlations with aftertaste, moistness, acid and bitter taste. For sweet taste this correlation was negative $\left(\mathrm{R}=-0.59^{*}\right)$. In broccoli and cauliflower Brückner et al. 
[27] showed that sweetness was high and negatively related to the total glucosinolate content, which in turn coincided closely with bitter and pungent taste.

Hydroxycinnamic acids and flavonoids had a slight relationship with the sensory traits evaluated in turnip tops. Therefore, it's worth pointing out that flavonoids kaempferol-3-O-(caffeoyl)sophoroside-7-O-glucoside and quercetin-3-O(caffeoyl)sophoroside-7-O-glucoside displayed correlations highest than $\mathrm{R}=0.60$ for leaf and stalk firmness (once again negatives) and for taste traits (acid, salty, bitter and aftertaste persistence). The highest coefficient correlation was found between salty taste and quercetin-3-O-(caffeoyl)sophoroside-7-O-glucoside $(\mathrm{R}=0.82)$. The highest difference between turnip greens and turnip tops was found in the hydroxycinnamic acids content. Turnip greens had $27 \mu \mathrm{m} \mathrm{g}^{-1}$ of hydroxycinnamic acids concentration and turnip tops $19.3 \mu \mathrm{m} \mathrm{g}^{-1}$, which can partially explain the less importance of this compounds on the flavor of turnip tops.

As summary, indolic and aromatic glucosinolates seem to be more related to traits indicative of texture while all glucosinolate types (indolic, aliphatic and aromatic) seems to affect considerably flavor traits, mainly bitterness, acid taste and aftertaste.

\section{Selection of sensorial traits}

Simple correlation coefficients among all sensory traits were calculated to determine which trait gives a better measure of sensorial value in turnip greens and turnip tops (Table 7). Two attributes related to product appearance, i.e. aroma intensity and leaf brightness and one trait related to preference, i.e. sharpness, were not correlated with any other trait. Therefore, these traits have not been useful to describe the flavor attributes of turnip tops and turnip greens but, depending on the consumer preferences may play a main role in the evaluation of the products. 
The highest correlation $(0.94 * *)$ was found between two traits related to hand texture, leaf firmness and stalk firmness. As it was previously explained, leaves and shoots are the plant parts consumed for turnip greens and for turnip tops, respectively. Thus, leaf firmness would be associated to turnip greens whereas stalk firmness would be associated to turnip tops. Regarding correlation coefficients altogether, three groups of relationships among the sensory traits evaluated could be differentiated. First, relations between traits linked to texture in hand (leaf firmness, stalk firmness, resistance to cutting) and texture in mouth as fibrosity. Coefficients among these traits were higher than $\mathrm{R}=0.86$ and the highest value $\left(\mathrm{R}=0.92^{* *}\right)$ was found between leaf firmness and fibrosity. This suggests that fibrosity of plant samples detected by panelist increased as leaves are more firmness. The second type of remarkable correlations was found between flavor traits (bitter, salty, and acid taste) and aftertaste persistence. It is well- known that a flavor more intense remains more time after eating, i.e. it is more persistent. In this case, the highest correlation was found between aftertaste persistence and bitterness $\left(\mathrm{R}=0.91^{* *}\right)$. Finally, the third kind of relationships was found between flavor traits (bitter, salty, acid and aftertaste and acid taste) with moistness in mouth. Among these, the highest coefficient value was found between bitterness and moistness $\left(\mathrm{R}=-0.89^{* *}\right)$. Coefficients were always negative suggesting that as moistness in mouth increase, scale values for bitter, acid, and salty tastes (but not for sweet taste) decrease. In addition, a significant and high correlation was also found among salty, acid and bitter tastes. A possible explanation is that flavor is probably very complex and difficult to evaluate objectively. The identification of each flavor trait separately is difficult because flavors are usually mixed and they are often misunderstanding.

\section{Conclusions}


Brassica rapa varieties from northwestern Spain showed differences in their sensory profiles. This variability could be used to select the best variety for sensorial characteristics according to vegetable market and consumer preferences. Secondary metabolites as glucosinolates and phenolic compounds, which play a crucial role in fruit and vegetable quality, were responsible of texture and flavor, depending on the organ evaluated. So, glucosinolates in turnip tops and hydroxycinnamic acids and flavonoids in turnip greens resulted to be related to some sensory traits responsible for taste and firmness. Regard to phenolic compounds, correlations with structural and flavor traits were found, thus indicate the relationship of these compounds and the cell wall integrity as well as provide characteristics taste. Hydroxycinnamic acids play a very important role in the life of the cell wall. They are principal components governing cell wall integrity, shape and defence against pathogenic access [28]. Glucosinolates, especially progoitrin (in turnip greens) and gluconapin (in turnip tops), showed a high correlation with flavor traits as bitter taste and aftertaste persistence. Hence, these compounds may be the main responsible for the bitter and pungent impression in these vegetables, which are frequently disliked and are one of the reasons for low consumer acceptability of some Brassica crops $[10,15,25]$. Some sensory traits evaluated in this study, mainly those related to texture as leaf and stalk firmness and resistance to cutting and those related to taste as bitter, salty and aftertaste could be used as important parameters for measuring the sensorial value of turnip tops and turnip greens. This first study has allowed us not only to define the sensory attributes of these crops but also to select those traits that they would be good candidates for a rapid screening of material. This invaluable information would help us to improve the quality and potential health value of turnip greens and turnip tops. 


\section{Acknowledgements}

Research supported by the Xunta de Galicia (PGIDIT06RAG40302PR) and Excma.

Diputación Provincial de Pontevedra. Marta Francisco acknowledges an I3P fellowship

from the CSIC. Authors tank the invaluable help of Rosaura Abilleira and Susana Calvo for all the laboratory work. 


\section{References}

1. Monteiro, A.A., \& Dias, J.S. (1996). Portuguese brassica landraces: A perspective. Proc. Int. Symposium on Brassicas. Ninth Crucifer genetics workshop. Acta Horticulturae ISHS 407: 87-93.

2. Padilla, G., Cartea, M.E., Rodríguez, V.M., \& Ordás, A., (2005). Genetic diversity in a germplasm collection of Brassica rapa subsp. rapa L. from northwestern Spain. Euphytica, 145, 171-180.

3. Bianco, V.V., Damato, G., \& Pomarici, R. (1996). Sowing and Transplant Dates in Four Cima Di Rapa (Brassica Rapa L.) Cultivars. I. Sowing Dates. International Symposium on Brassicas, Ninth Crucifer Genetics Workshop (eds Dias, J.S., Crute, I. and Monteiro, A.A.), 64, 293-298.

4. Rosa, E.A.S. 1997. Glucosinolates from flower buds of Portuguese Brassica crops. Phytochemistry 44 (8), 1415-1419.

5. Padilla, G., Cartea, M. E., Velasco, P., de Haro, A., \& Ordás, A. (2007). Variation of glucosinolates in vegetable crops of Brassica rapa. Phytochemistry, 68, 536-545.

6. Traka, M., \& Mithen, R. (2008). Glucosinolates, isothiocyanates and human health. Phytochemistry Reviews, 8, 293-298.

7. Fenwick, G. R., Heaney, R. K., \& Mullin, W. J. (1983a) Glucosinolates and their breakdown products in food and feedingstuffs. Critical Reviews in Food Science and Nutrition, 18, 123-206.

8. van Doorn, H. E., van der Kruk, G. C., van Holst, G. J., Raaijmakers-Ruijs, N., Postma, E., Groeneweg, B., \& Jongen, W. H. F. (1998). The glucosinolates sinigrin and progoitrin are important determinants for taste preference and bitterness of brussels sprouts. Journal of the Science of Food and Agriculture, $78,30-38$.

9. Engel, E., Baty, C., Le Corre, D., Souchon, I., \& Martin, N. (2002). Flavor-active compounds potentially implicated in cooked cauliflower acceptance. Journal of Agricultural and Food Chemistry, 50, 6459-6467.

10. Schonhof, I., Krumbein, A., \& Bruckner, B. (2004). Genotypic effects on glucosinolates and sensory properties of broccoli and cauliflower. NahrungFood, 48, 25-33.

11. Moskowitz, H. (1983). Descriptive analysis of perceptions. In Product testing and sensory evaluation of foods (pp. 20-78). Westport, CT: Food Nutrition Press.

12. Fenwick, G. R., Griffiths, N. M., \& Heaney, R. K. (1983b). Bitterness in Brussels sprouts (Brassica oleracea L. Var. Gemmifera): Te role of glucosinolates and their breakdown products. Journal of the Science of Food and Agriculture, 34, 73-80.

13. Hansen, M., Laustsen, A. M., Olsen, C. E., Poll, L., \& Sorensen, H. (1997). Chemical and sensory quality of broccoli (Brassica oleracea L. var italica). Journal of Food Quality, 20, 441-459.

14. Baik, H. Y., Juvik, J., Jeffery, E. H., Wallig, M. A., Kushad, M., \& Klein, B. P. (2003). Relating glucosinolate content and flavor of broccoli cultivars. Journal of Food Science, 68, 1043-1050.

15. Jones, G., \& Sanders, O.G. (2002). A sensory profile of turnip greens as affected by variety and maturity. Journal of Food Science, 67, 3126-3129.

16. Alonso-Fernández, B., Arias Carmona, M.D., Fernández-Fernández, E., RomeroRodríguez, M.A., Vázquez-Odériz, M.L., \& Muñóz-Ferreiro, N. (2003). 
Generación de descriptores y entrenamiento del panel para la evaluación sensorial del grelo (Brassica rapa, L). III Simposium Iberoamericano de Análisis Sensorial SENSIBER. Montevideo (Uruguay).

17. ISO 8586-1:1993 (1993). Sensory Analysis. General guidance for the selection, training and monitoring of assessors. Part 1: selected judges. Geneva, International Organization for Standardization.

18. ISO 11035:1994 (1994). Sensory analysis. Identification and selection of descriptors for establishing a sensory profile by a multidimensional approach. Geneva, International Organization for Standardization.

19. ISO 4121:1987 (1997). Sensory analysis. Methodology. Evaluation of food products by methods using scales. Geneva, International Organization for Standardization.

20. Steel, R.D.G., Torrie, J.H., Dickey, D.A. (1997). Principles and Procedures in Statistics: A Biometrical Approach. 3rd Ed. Mc Graw Hill, New York.

21. Francisco, M., Moreno, D.A., Cartea M.E., Ferreres, F., García-Viguera, C., \& Velasco, P. (2009). Simultaneous identification of glucosinolates and phenolic compounds in a representative collection of vegetable Brassica rapa. Journal of Chromatography A (accepted).

22. SAS Institute Inc. (2000). SAS Online Doc, version 8. SAS Institute Inc, Cary, NC, USA.

23. Walters, D.E. (1996). How are Bitter and Sweet Tastes Related? Trends in Food Science \& Technology, 7, 399-403.

24. Troszyńska, A. (2004). Non-nutrient bioactive substances in food of plant origin causing bitterness and astringency. Polish Journal of Food And Nutrition Sciences, 13/54: 65-73.

25. Drewnowski, A., \& Gomez-Carneros, C. (2000). Bitter taste, phytonutrients, and the consumer: A review. American Journal of Clinical Nutrition, 72, 1424-1435.

26. Shin, W. H.., Kim, S. J.; \& Shin, J. M.(1995). Structure-taste correlations in sweet dihydrochalcone, sweet dihydroisocoumarin and bitter flavone compounds. Journal of Medicinal Chemistry. 38, 4325-4331.

27. Brückner, B., Schonhof, I., Kornelson, C., \& Schrodter, R. (2005). Multivariate sensory profile of broccoli and cauliflower and consumer preference. Italian Journal of Food Science, 17, 17-32.

28. Faulds, C.B., \& Williamson, G. (1999). The role of hydroxycinnamates in the plant cell wall. Journal of The Science of Food and Agriculture, 79, 393-395. 
Table 1. Local varieties of B. rapa evaluated in this study.

\begin{tabular}{|l|l|l|c|}
\hline \multicolumn{1}{|c|}{ Code Name } & \multicolumn{1}{|c|}{ Origin } & Source $^{1}$ & Type $^{2}$ \\
\hline MBG-BRS0082 & Vilar, Forcarei, Pontevedra & MBG & L \\
\hline MBG-BRS0143 & Lama, Boqueixón, A Coruña & MBG & L \\
\hline MBG-BRS0163 & Barcia, Melón, Ourense & MBG & S \\
\hline MBG-BRS0173 & Valongo, Cortejada, Ourense & MBG & L \\
\hline MBG-BRS0184 & Carballo, A Coruña & MBG & L \\
\hline MBG-BRS0197 & Arnoia, Ourense & MBG & S \\
\hline MBG-BRS0401 & San Xiao, Coirós, A Coruña & MBG & L \\
\hline MBG-BRS0433 & Santiago, A Coruña & MBG & L \\
\hline MBG-BRS0451 & O Val, Narón, A Coruña & MBG & L \\
\hline MBG-BRS0461 & Castro de Rei, Lugo & MBG & L \\
\hline MBG-BRS0472 & Porta, Sobrado, A Coruña & MBG & L \\
\hline MBG-BRS0550 & Trazo, A Coruña & MBG & L \\
\hline
\end{tabular}

${ }^{1}$ Germplasm bank of the Misión Biológica of Galicia (MBG).

${ }^{2} \mathrm{~L}=$ Local variety (without selection), $\mathrm{S}=$ Variety derived from three cycles of masal selection by fresh yield. 
Table 2. Sensory traits evaluated in this study using a $10-\mathrm{cm}$ no structured intensity scales (ISO 4121:1987) according to Alonso-Fernández et al. (2003).

\section{INTENSITY SCALE}

Trait 1 10

\section{External aspect}

Leaf color $^{1}$

$3975 u$

Dry olive

Leaf brightness

Aroma

Aroma intensity

Weak

Strong

Texture in hand

Stalk firmness

Leaf firmness

Resistance to cutting

Texture in mouth

Moistness in mouth

Fibrosity in mouth

Sharpness

Sticks to palate
Spaghuetti 5'

Spaghuetti 5'

Asparagus tops

Apple

Bean

Asparagus tops

Eggplant

Egg white
$5815 \mathrm{u}$

Wet olive
Spaghuetti 15'

Spaghuetti 15,

Asparagus stalks
Asparagus stalks

Bean

Pate 
Flavor

Bitter taste

Acid taste

Sweet taste

Salty taste
Weak

Weak

Weak

Weak

Aftertaste persistence $^{2}<10 \mathrm{~s}$
Strong

Strong

Strong

Strong

$60 \mathrm{~s}$

${ }^{1}$ Pantone ${ }^{\circledR}$ COLOR SCALE

${ }^{2}$ Time in seconds 
1 Table 3. Mean squares of the combined analysis of variance across four environments

2 for sensory traits in the 12 B. rapa varieties (turnip greens and turnip tops) from

3 northwestern Spain.

\begin{tabular}{|c|c|c|c|c|c|c|}
\hline & \multicolumn{4}{|c|}{ Turnip greens } & \multicolumn{2}{|r|}{ Turnip tc } \\
\hline & Environment (E) & Variety (V) & $\mathrm{E} \times \mathrm{V}$ & Error & Environment (E) & Variety \\
\hline Aroma intensity & $2.495^{*}$ & $1.723^{*}$ & 0.763 & 1.989 & 2.004 & 1.50 \\
\hline Leaf color & 5.736 & $9.740 *$ & 4.285 & 3.188 & 2.913 & 11.94 \\
\hline Leaf brightness & 4.519 & 2.538 & $4.883 * *$ & 2.309 & $29.387 * *$ & 5.44 \\
\hline Stalk firmness & $389.217 * *$ & 3.728 & 6.084 & 4.110 & $391.556 * *$ & 8.25 \\
\hline Leaf firmness & $91.786 * *$ & 8.501 & 11.693 & 8.709 & $111.577 * *$ & 10.01 \\
\hline $\begin{array}{l}\text { Resistance to } \\
\text { cutting }\end{array}$ & $36.377 * *$ & 7.668 & $7.813 * *$ & 3.446 & $22.440 * *$ & 18.26 \\
\hline $\begin{array}{l}\text { Moistness in } \\
\text { mouth }\end{array}$ & $14.005^{* *}$ & 0.858 & 2.018 & 2.986 & $6.519^{*}$ & 4.30 \\
\hline $\begin{array}{l}\text { Fibrosity in } \\
\text { mouth }\end{array}$ & $12.411^{*}$ & 3.392 & 3.957 & 3.938 & 6.898 & 7.18 \\
\hline Sharpness & $25.343 * *$ & 3.704 & $4.358^{*}$ & 2.519 & $20.719 * *$ & 8.59 \\
\hline Sticks to palate & $11.091 * *$ & 1.033 & 1.340 & 2.084 & 0.773 & 2.39 \\
\hline Bitter taste & $16.088 * *$ & 3.583 & 2.570 & 2.340 & $11.650 * *$ & 5.18 \\
\hline Acid taste & $14.925^{* *}$ & 1.561 & 1.435 & 4.401 & $22.136 * *$ & 2.59 \\
\hline Sweet taste & $10.491 * *$ & 0.957 & 1.183 & 3.543 & $13.486^{* *}$ & 2.21 \\
\hline Salty taste & $12.786^{* *}$ & $4.705^{*}$ & 1.612 & 3.272 & $31.847 * *$ & 2.51 \\
\hline Aftertaste & 1.560 & 2.431 & 2.347 & 2.128 & $8.124^{*}$ & 3.33 \\
\hline
\end{tabular}

4 $*, * *$ Significant at the 0.05 and 0.01 probability levels, respectively. 
6 Table 4. Mean of sensory traits for the 12 turnip greens varieties evaluated in this study

7 in two locations and two years in northwestern Spain.

\begin{tabular}{|c|c|c|c|c|c|c|c|}
\hline Variety & $\begin{array}{l}\text { Aroma } \\
\text { intensity }\end{array}$ & $\begin{array}{l}\text { Leaf } \\
\text { color }\end{array}$ & $\begin{array}{c}\text { Leaf } \\
\text { brightness }\end{array}$ & $\begin{array}{c}\text { Stalk } \\
\text { firmness }\end{array}$ & $\begin{array}{c}\text { Leaf } \\
\text { firmness }\end{array}$ & $\begin{array}{l}\text { Resistance } \\
\text { to cutting }\end{array}$ & Mr \\
\hline MBG-BRS0082 & $5.64 \mathrm{ab}$ & $6.04 b c$ & $5.57 \mathrm{ab}$ & $5.07 \mathrm{a}$ & $4.83 \mathrm{ab}$ & $5.07 b c$ & 1 \\
\hline MBG-BRS0143 & $5.14 \mathrm{ab}$ & $6.48 \mathrm{abc}$ & $5.62 \mathrm{ab}$ & $4.81 \mathrm{ab}$ & $5.87 \mathrm{a}$ & $5.76 \mathrm{ab}$ & - \\
\hline MBG-BRS0163 & $4.85 b$ & $7.30 \mathrm{a}$ & $5.39 \mathrm{ab}$ & $1.44 \mathrm{~d}$ & $2.40 \mathrm{c}$ & $4.29 c$ & : \\
\hline MBG-BRS0173 & $5.40 \mathrm{ab}$ & $6.35 \mathrm{abc}$ & $5.36 \mathrm{ab}$ & $4.75 \mathrm{ab}$ & $4.70 \mathrm{ab}$ & $5.60 \mathrm{ab}$ & 1 \\
\hline MBG-BRS0184 & $5.19 \mathrm{ab}$ & $5.87 \mathrm{~cd}$ & $5.39 \mathrm{ab}$ & $5.33 \mathrm{a}$ & $5.08 \mathrm{ab}$ & $5.30 b c$ & 1 \\
\hline MBG-BRS0197 & $5.14 \mathrm{ab}$ & $6.15 b c$ & $4.47 \mathrm{c}$ & $2.97 \mathrm{c}$ & $3.90 b c$ & $5.15 b c$ & 1 \\
\hline MBG-BRS0401 & $4.96 \mathrm{ab}$ & $6.90 \mathrm{abc}$ & $5.69 \mathrm{a}$ & $4.74 \mathrm{ab}$ & $4.54 \mathrm{ab}$ & $5.34 b c$ & 1 \\
\hline MBG-BRS0433 & $5.26 \mathrm{ab}$ & $6.43 a b c$ & $5.62 \mathrm{ab}$ & $3.81 \mathrm{bc}$ & $3.98 \mathrm{bc}$ & $5.98 \mathrm{ab}$ & 1 \\
\hline MBG-BRS0451 & $5.61 \mathrm{ab}$ & $7.05 \mathrm{ab}$ & $5.54 \mathrm{ab}$ & $5.24 \mathrm{a}$ & $6.02 \mathrm{a}$ & $6.49 \mathrm{a}$ & 1 \\
\hline MBG-BRS0461 & $5.73 a$ & $4.90 \mathrm{~d}$ & $5.51 \mathrm{ab}$ & $5.17 \mathrm{a}$ & $5.23 \mathrm{ab}$ & $4.96 b c$ & 1 \\
\hline MBG-BRS0472 & $4.99 \mathrm{ab}$ & $6.40 \mathrm{abc}$ & $4.77 b c$ & $5.15 \mathrm{a}$ & $4.90 \mathrm{ab}$ & $5.24 b c$ & 1 \\
\hline MBG-BRS0550 & $5.22 \mathrm{ab}$ & $6.84 \mathrm{abc}$ & $5.32 \mathrm{abc}$ & $5.26^{\mathrm{a}}$ & $5.24 \mathrm{ab}$ & $5.96 \mathrm{ab}$ & - \\
\hline Variety & Sharpness & $\begin{array}{c}\text { Sticks to } \\
\text { palate }\end{array}$ & Bitter taste & Acid taste & Sweet taste & Salty taste & A \\
\hline MBG-BRS0082 & $4.77 \mathrm{abc}$ & $3.43 b$ & $5.92 \mathrm{~cd}$ & $3.15 b$ & $3.16 a$ & $3.58 b$ & 1 \\
\hline MBG-BRS0143 & $5.17 \mathrm{ab}$ & $3.69 \mathrm{ab}$ & $6.21 \mathrm{bcd}$ & $3.66 \mathrm{ab}$ & $3.11 \mathrm{a}$ & $4.26 \mathrm{ab}$ & 1 \\
\hline MBG-BRS0163 & $4.73 \mathrm{abc}$ & $4.46 \mathrm{a}$ & $7.11 \mathrm{a}$ & $4.42 \mathrm{a}$ & $2.99 \mathrm{a}$ & $5.08 \mathrm{a}$ & ' \\
\hline MBG-BRS0173 & $5.55 \mathrm{a}$ & $4.07 \mathrm{ab}$ & $6.85 \mathrm{ab}$ & $3.92 \mathrm{ab}$ & $2.92 \mathrm{a}$ & $4.58 \mathrm{ab}$ & , \\
\hline
\end{tabular}




\begin{tabular}{|c|c|c|c|c|c|c|c|}
\hline MBG-BRS0184 & $5.03 \mathrm{abc}$ & $3.31 \mathrm{~b}$ & $6.19 \mathrm{bcd}$ & $3.59 \mathrm{ab}$ & $2.86 a$ & $3.99 b$ & 1 \\
\hline MBG-BRS0197 & $5.29 a$ & $4.00 \mathrm{ab}$ & $6.81 \mathrm{abc}$ & $3.78 \mathrm{ab}$ & $3.11 \mathrm{a}$ & $5.20 \mathrm{a}$ & ' \\
\hline MBG-BRS0401 & $5.42 \mathrm{a}$ & $4.01 \mathrm{ab}$ & 6.49abcd & $3.80 \mathrm{ab}$ & $2.83 a$ & $4.58 \mathrm{ab}$ & 1 \\
\hline MBG-BRS0433 & $5.44 \mathrm{a}$ & $3.83 \mathrm{ab}$ & $5.94 \mathrm{~cd}$ & $3.19 b$ & $3.20 \mathrm{a}$ & $4.15 \mathrm{ab}$ & 1 \\
\hline MBG-BRS0451 & $5.02 \mathrm{abc}$ & $3.66 \mathrm{ab}$ & $5.74 d$ & $3.41 \mathrm{ab}$ & $3.38 \mathrm{a}$ & $3.82 \mathrm{~b}$ & 1 \\
\hline MBG-BRS0461 & $4.25 b c$ & $3.74 \mathrm{ab}$ & $6.35 \mathrm{abc}$ & $3.65 \mathrm{ab}$ & $3.03 \mathrm{a}$ & $3.54 b$ & 1 \\
\hline MBG-BRS0472 & $4.88 \mathrm{abc}$ & $3.87 \mathrm{ab}$ & $6.18 \mathrm{bcd}$ & $3.41 \mathrm{ab}$ & $3.01 \mathrm{a}$ & $4.48 \mathrm{ab}$ & 1 \\
\hline MBG-BRS0550 & $4.18 c$ & $3.48 b$ & $5.79 \mathrm{~d}$ & $3.43 \mathrm{ab}$ & $3.33 \mathrm{a}$ & \multicolumn{2}{|c|}{$\begin{array}{l}\text { 4.37 } \mathrm{ah} \\
\text { Con formato: Inglés (Estados } \\
\text { Unidos) }\end{array}$} \\
\hline
\end{tabular}


Table 5. Mean of sensory traits for the 12 turnip tops varieties evaluated in this study in

11 two locations and two years in northwestern Spain.

\begin{tabular}{|c|c|c|c|c|c|c|c|}
\hline Variety & $\begin{array}{l}\text { Aroma } \\
\text { Intensity }\end{array}$ & $\begin{array}{l}\text { Leaf } \\
\text { color }\end{array}$ & $\begin{array}{c}\text { Leaf } \\
\text { brightness }\end{array}$ & $\begin{array}{c}\text { Stalk } \\
\text { firmness }\end{array}$ & $\begin{array}{c}\text { Leaf } \\
\text { firmness }\end{array}$ & $\begin{array}{l}\text { Resistance } \\
\text { to cutting }\end{array}$ & $\begin{array}{r}\text { Moistn } \\
\text { mol }\end{array}$ \\
\hline MBG-BRS0082 & $5.37 \mathrm{a}$ & $5.26 \mathrm{bc}$ & $5.31 \mathrm{ab}$ & $3.96 \mathrm{~d}$ & $4.47 b c$ & $5.88 \mathrm{ab}$ & $6.92 \mathrm{ab}$ \\
\hline MBG-BRS0143 & $5.26 \mathrm{a}$ & $3.47 \mathrm{~d}$ & $4.87 \mathrm{abc}$ & $5.63 \mathrm{ab}$ & $4.83 b c$ & $6.29 \mathrm{a}$ & $6.86 \mathrm{ab}$ \\
\hline MBG-BRS0163 & $5.89 \mathrm{a}$ & $6.90 \mathrm{a}$ & $5.11 \mathrm{abc}$ & $0.80 \mathrm{e}$ & $2.11 \mathrm{~d}$ & $2.52 \mathrm{e}$ & $6.58 \mathrm{abr}$ \\
\hline MBG-BRS0173 & $5.53 \mathrm{a}$ & $5.22 b c$ & $5.60 \mathrm{a}$ & $5.05 \mathrm{abcd}$ & $5.36 \mathrm{ab}$ & $5.75 \mathrm{ab}$ & $6.67 \mathrm{abr}$ \\
\hline MBG-BRS0184 & $6.00 \mathrm{a}$ & $5.35 b c$ & $4.82 \mathrm{abc}$ & $4.00 \mathrm{~d}$ & $4.62 b c$ & $5.45 \mathrm{abc}$ & $6.70 \mathrm{abr}$ \\
\hline MBG-BRS0197 & $5.57 \mathrm{a}$ & $5.86 a b$ & $5.18 \mathrm{abc}$ & $1.18 \mathrm{e}$ & $3.68 \mathrm{c}$ & $3.51 \mathrm{de}$ & $5.61 \mathrm{c}$ \\
\hline MBG-BRS0401 & $5.52 \mathrm{a}$ & $5.27 \mathrm{bc}$ & $5.34 \mathrm{ab}$ & $4.39 \mathrm{bcd}$ & $5.11 \mathrm{ab}$ & $4.45 \mathrm{bcd}$ & $6.45 b c$ \\
\hline MBG-BRS0433 & $5.30 \mathrm{a}$ & $4.14 \mathrm{~cd}$ & $4.60 b c$ & $5.23 \mathrm{abcd}$ & $5.11 \mathrm{ab}$ & $6.07 \mathrm{a}$ & $7.08 \mathrm{ab}$ \\
\hline MBG-BRS0451 & $5.54 \mathrm{a}$ & $4.56 \mathrm{~cd}$ & $5.33 \mathrm{ab}$ & $5.80 \mathrm{a}$ & $5.48 \mathrm{ab}$ & 4.89abcd & $7.32 \mathrm{ab}$ \\
\hline MBG-BRS0461 & $5.65 \mathrm{a}$ & $4.75 b c$ & $5.00 \mathrm{abc}$ & $4.27 \mathrm{~cd}$ & $4.22 b c$ & 4.95abcd & $7.55 \mathrm{ab}$ \\
\hline MBG-BRS0472 & $5.55 \mathrm{a}$ & $5.02 \mathrm{bc}$ & $4.33 \mathrm{c}$ & $5.32 \mathrm{abc}$ & $5.05 b$ & $4.09 \mathrm{~cd}$ & $7.70 \mathrm{a}$ \\
\hline MBG-BRS0550 & $5.07 \mathrm{a}$ & $4.21 \mathrm{~cd}$ & $4.70 \mathrm{abc}$ & $5.46 \mathrm{abc}$ & $6.48 \mathrm{a}$ & $5.03 \mathrm{abcd}$ & $7.08 \mathrm{ab}$ \\
\hline
\end{tabular}

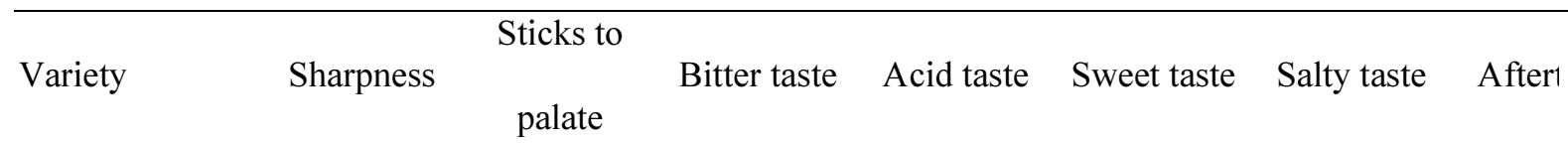

\begin{tabular}{llllllll}
\hline MBG-BRS0082 & $4.93 \mathrm{a}$ & $4.08 \mathrm{ab}$ & $6.73 \mathrm{bc}$ & $3.61 \mathrm{~b}$ & $3.11 \mathrm{a}$ & $4.17 \mathrm{bc}$ & $6.72 \mathrm{~b}$ \\
MBG-BRS0143 & $4.58 \mathrm{ab}$ & $4.24 \mathrm{ab}$ & $6.21 \mathrm{bcd}$ & $3.38 \mathrm{~b}$ & $3.20 \mathrm{a}$ & $5.00 \mathrm{ab}$ & $6.82 \mathrm{a}$ \\
MBG-BRS0163 & $4.40 \mathrm{ab}$ & $4.38 \mathrm{ab}$ & $7.23 \mathrm{ab}$ & $4.28 \mathrm{ab}$ & $2.48 \mathrm{a}$ & $4.66 \mathrm{abc}$ & $7.29 \mathrm{ak}$ \\
MBG-BRS0173 & $5.00 \mathrm{a}$ & $3.98 \mathrm{ab}$ & $7.10 \mathrm{ab}$ & $4.19 \mathrm{ab}$ & $2.68 \mathrm{a}$ & $4.55 \mathrm{abc}$ & $7.23 \mathrm{a}$ \\
MBG-BRS0184 & $4.97 \mathrm{a}$ & $3.90 \mathrm{ab}$ & $6.87 \mathrm{bc}$ & $4.19 \mathrm{ab}$ & $3.19 \mathrm{a}$ & $4.24 \mathrm{bc}$ & $7.10 \mathrm{a}$ \\
MBG-BRS0197 & $4.88 \mathrm{a}$ & $4.85 \mathrm{a}$ & $8.00 \mathrm{a}$ & $5.28 \mathrm{a}$ & $3.15 \mathrm{a}$ & $5.71 \mathrm{a}$ & $7.92 \mathrm{a}$
\end{tabular}




$\begin{array}{llllllll}\text { MBG-BRS0401 } & 4.40 \mathrm{ab} & 4.11 \mathrm{ab} & 6.98 \mathrm{abc} & 4.00 \mathrm{ab} & 2.63 \mathrm{a} & 4.32 \mathrm{bc} & 6.78 \mathrm{~b} \\ \text { MBG-BRS0433 } & 5.27 \mathrm{a} & 4.65 \mathrm{ab} & 6.40 \mathrm{bcd} & 3.18 \mathrm{~b} & 3.01 \mathrm{a} & 3.96 \mathrm{bc} & 6.80 \mathrm{ak} \\ \text { MBG-BRS0451 } & 3.82 \mathrm{bc} & 3.68 \mathrm{~b} & 6.95 \mathrm{bc} & 3.93 \mathrm{ab} & 3.28 \mathrm{a} & 4.34 \mathrm{bc} & 6.59 \mathrm{~b} \\ \text { MBG-BRS0461 } & 3.81 \mathrm{bc} & 3.82 \mathrm{ab} & 6.34 \mathrm{bcd} & 3.74 \mathrm{ab} & 3.43 \mathrm{a} & 4.46 \mathrm{abc} & 6.54 \mathrm{~b} \\ \text { MBG-BRS0472 } & 3.10 \mathrm{c} & 4.09 \mathrm{ab} & 5.61 \mathrm{~d} & 3.38 \mathrm{~b} & 2.84 \mathrm{a} & 3.48 \mathrm{c} & 6.29 \mathrm{~b} \\ \text { MBG-BRS0550 } & 4.47 \mathrm{ab} & 4.44 \mathrm{ab} & 5.98 \mathrm{~cd} & 3.54 \mathrm{~b} & 3.04 \mathrm{a} & 4.39 \mathrm{bc} & 6.19 \mathrm{~b}\end{array}$

12 Means with the same letter in the same column are not significant different at $P \leq 0.05$. 
(A)

\begin{tabular}{|c|c|c|c|c|c|c|c|}
\hline \multirow[t]{2}{*}{ Turnip greens } & \multicolumn{4}{|c|}{ Glucosinolates } & \multicolumn{3}{|c|}{ Phenolic compounds } \\
\hline & $\begin{array}{c}\text { Alipha } \\
\text { tic }\end{array}$ & $\begin{array}{l}\text { Indo } \\
\text { lic }\end{array}$ & $\begin{array}{l}\text { Arom } \\
\text { atic }\end{array}$ & Total & $\begin{array}{l}\text { Flavono } \\
\text { ids }\end{array}$ & $\begin{array}{l}\text { Hydroxycinn } \\
\text { amic acids }\end{array}$ & Total \\
\hline Aroma intensity & 0.22 & 0.11 & 0.03 & 0.17 & 0.16 & 0.57 & 0.50 \\
\hline Leaf color & 0.18 & 0.20 & 0.17 & 0.23 & 0.03 & -0.38 & -0.28 \\
\hline Leaf brightness & 0.32 & 0.20 & 0.09 & 0.27 & -0.24 & 0.27 & 0.11 \\
\hline Stalk firmness & 0.51 & $\begin{array}{c}- \\
0.49\end{array}$ & -0.02 & 0.41 & 0.46 & $0.85^{* *}$ & 0.82 \\
\hline Leaf firmness & 0.43 & $\begin{array}{c}- \\
0.28\end{array}$ & 0.07 & 0.35 & 0.57 & 0.73 & 0.77 \\
\hline $\begin{array}{l}\text { Resistance to } \\
\text { cutting }\end{array}$ & 0.44 & 0.02 & 0.28 & 0.42 & 0.54 & 0.42 & 0.51 \\
\hline $\begin{array}{l}\text { Moistness in } \\
\text { mouth }\end{array}$ & 0.51 & $\begin{array}{c}- \\
0.33\end{array}$ & 0.09 & 0.43 & 0.51 & $0.74 * *$ & $0.75^{* *}$ \\
\hline $\begin{array}{l}\text { Fibrosity in } \\
\text { mouth }\end{array}$ & 0.32 & $\begin{array}{c}- \\
0.30\end{array}$ & 0.05 & 0.25 & 0.57 & 0.55 & $0.63^{*}$ \\
\hline Sharpness & 0.22 & $\begin{array}{c}- \\
0.34\end{array}$ & -0.15 & 0.25 & -0.11 & -0.28 & -0.27 \\
\hline Sticks to palate & -0.03 & $\begin{array}{c}- \\
0.04\end{array}$ & -0.51 & 0.07 & -0.54 & $-0.72 * *$ & $-0.75^{* *}$ \\
\hline Bitter taste & 0.01 & 0.01 & -0.55 & 0.10 & -0.58 & $-0.76^{* *}$ & $-0.79 * *$ \\
\hline Acid taste & 0.11 & 0.26 & -0.21 & 0.19 & $-0.64 *$ & $-0.76^{* *}$ & $-0.82 * *$ \\
\hline Sweet taste & 0.10 & 0.37 & 0.42 & 0.11 & 0.54 & 0.36 & 0.47 \\
\hline Salty taste & -0.05 & 0.20 & -0.28 & 0.05 & -0.16 & $-0.79 * *$ & $-0.67 *$ \\
\hline
\end{tabular}




\begin{tabular}{|l|l|l|l|l|l|l|l|}
\hline Aftertaste & 0.41 & 0.02 & -0.44 & 0.50 & -0.42 & $-0.58^{*}$ & $-0.61 *$ \\
\hline
\end{tabular}

*, ** Significant at the 0.05 and 0.01 probability levels, respectively.

\begin{tabular}{|c|c|c|c|c|c|c|c|}
\hline \multirow[t]{2}{*}{ Turnip tops } & \multicolumn{4}{|c|}{ Glucosinolates } & \multicolumn{3}{|c|}{ Phenolic compounds } \\
\hline & $\begin{array}{l}\text { Alipha } \\
\text { tic }\end{array}$ & $\begin{array}{c}\text { Indo } \\
\text { lic }\end{array}$ & $\begin{array}{c}\text { Aroma } \\
\text { tic }\end{array}$ & Total & $\begin{array}{c}\text { Flavono } \\
\text { ids }\end{array}$ & $\begin{array}{l}\text { Hydroxycinn } \\
\text { amic acids }\end{array}$ & Total \\
\hline Aroma intensity & 0.31 & 0.36 & 0.35 & 0.37 & 0.26 & 0.47 & 0.41 \\
\hline Leaf color & 0.55 & $\begin{array}{c}0.76 \\
* *\end{array}$ & $0.73 * *$ & $0.61 *$ & 0.27 & 0.43 & 0.39 \\
\hline Leaf brightness & 0.55 & 0.33 & 0.42 & 0.55 & 0.11 & 0.35 & 0.27 \\
\hline Stalk firmness & -0.38 & $\begin{array}{c}- \\
0.88 \\
* *\end{array}$ & $\begin{array}{c}- \\
0.76^{* *}\end{array}$ & -0.46 & -0.23 & -0.36 & -0.33 \\
\hline Leaf firmness & -0.05 & $\begin{array}{c}- \\
0.58 \\
*\end{array}$ & $-0.65^{*}$ & -0.17 & -0.30 & -0.50 & -0.47 \\
\hline $\begin{array}{l}\text { Resistance to } \\
\text { cutting }\end{array}$ & -0.31 & $\begin{array}{c}- \\
0.70 \\
* *\end{array}$ & $-0.68 *$ & -0.39 & -0.19 & -0.10 & -0.15 \\
\hline $\begin{array}{l}\text { Moistness in } \\
\text { mouth }\end{array}$ & $-0.60 *$ & $\begin{array}{c}- \\
0.59 \\
*\end{array}$ & -0.58 & $-0.62 *$ & 0.01 & -0.11 & -0.06 \\
\hline $\begin{array}{l}\text { Fibrosity in } \\
\text { mouth }\end{array}$ & 0.01 & $\begin{array}{c}- \\
0.48\end{array}$ & -0.45 & -0.07 & -0.30 & -0.30 & -0.33 \\
\hline Sharpness & 0.32 & 0.13 & -0.05 & 0.26 & -0.19 & 0.21 & 0.04 \\
\hline Sticks to palate & 0.27 & 0.44 & 0.30 & 0.27 & -0.29 & -0.01 & -0.14 \\
\hline Bitter taste & $0.65 *$ & $\begin{array}{c}0.68 \\
*\end{array}$ & $0.67 *$ & $0.70^{*}$ & 0.07 & 0.22 & 0.17 \\
\hline Acid taste & $0.69 *$ & 0.74 & $0.70^{*}$ & $0.73 *$ & 0.09 & 0.05 & 0.07 \\
\hline
\end{tabular}




\begin{tabular}{|l|c|c|c|c|c|c|c|}
\hline & & $* *$ & & $*$ & & & \\
\hline Sweet taste & -0.54 & - & -0.55 & $-0.58^{*}$ & -0.13 & -0.38 & -0.30 \\
\hline Salty taste & 0.36 & 0.57 & 0.53 & 0.40 & 0.17 & 0.06 & 0.12 \\
\hline Aftertaste & $0.61 *$ & 0.61 & $0.70^{*}$ & $0.67 *$ & 0.04 & 0.27 & 0.19 \\
\hline
\end{tabular}

19

20

*, ** Significant at the 0.05 and 0.01 probability levels, respectively. 


\begin{tabular}{|c|c|c|c|c|c|c|c|c|c|c|}
\hline & $\mathrm{LC}$ & BR & $\mathrm{SF}$ & LF & $\mathrm{RC}$ & $\mathrm{MM}$ & FM & $\mathrm{SH}$ & SP & BT \\
\hline AI & -0.21 & 0.37 & 0.05 & -0.01 & 0.03 & 0.15 & -0.14 & -0.17 & -0.44 & 0.17 \\
\hline $\mathrm{LC}$ & & -0.03 & $-0.65^{*}$ & $-0.62 *$ & $-0.68^{*}$ & $-0.67 *$ & $-0.62 *$ & 0.15 & 0.51 & $0.61 *$ \\
\hline BR & & & 0.27 & 0.20 & 0.37 & 0.11 & 0.24 & 0.33 & -0.21 & 0.16 \\
\hline SF & & & & $0.94 * *$ & $0.86 * *$ & $0.90 * *$ & $0.87 * *$ & -0.12 & $-0.74 * *$ & $-0.74 * *$ \\
\hline $\mathrm{LF}$ & & & & & $0.87 * *$ & $0.76^{* *}$ & $0.92 * *$ & -0.10 & $-0.71 *$ & $-0.67 *$ \\
\hline $\mathrm{RC}$ & & & & & & $0.68 *$ & $0.91 * *$ & 0.26 & -0.54 & $-0.60 *$ \\
\hline MM & & & & & & & $0.60 *$ & -0.43 & $-0.77 * *$ & $-0.89 * *$ \\
\hline FM & & & & & & & & 0.25 & -0.53 & -0.56 \\
\hline $\mathrm{SH}$ & & & & & & & & & 0.38 & 0.39 \\
\hline SP & & & & & & & & & & $0.66^{*}$ \\
\hline BT & & & & & & & & & & \\
\hline $\mathrm{AT}$ & & & & & & & & & & \\
\hline SWT & & & & & & & & & & \\
\hline SLT & & & & & & & & & & \\
\hline
\end{tabular}

Table 7. Simple correlations among sensory traits on 12 B. rapa varieties grown in four environments in northwestern Spain. 
Figure 1. Graphic representation of (A) Minimum and maximum temperatures and (B)

Figure 2. Descriptive sensory analysis of twelve varieties in turnip greens (A) and turnip tops (B). For abreviations see Table 7.

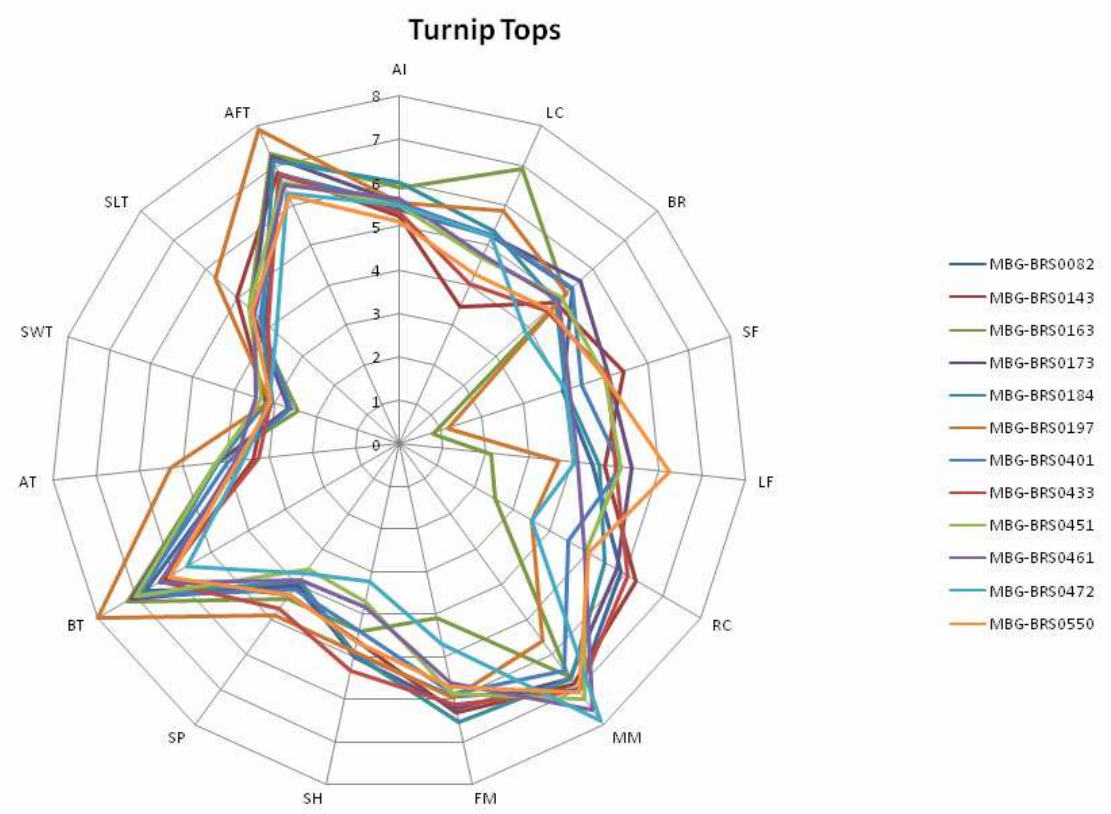

36

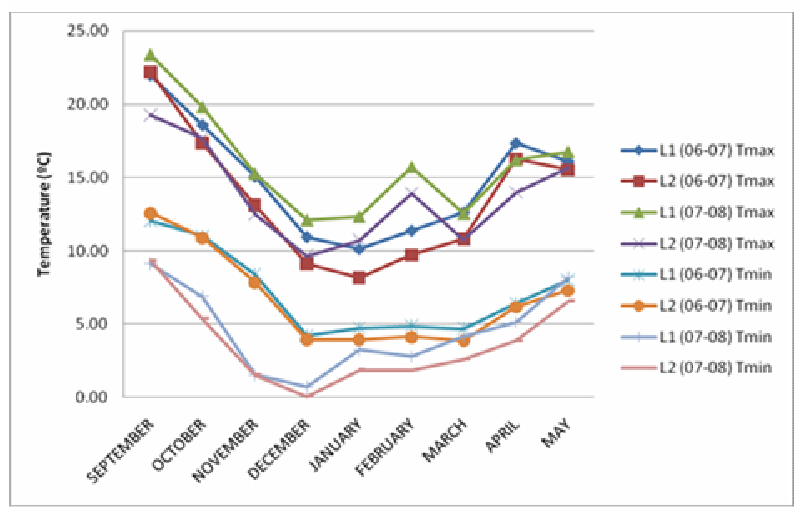



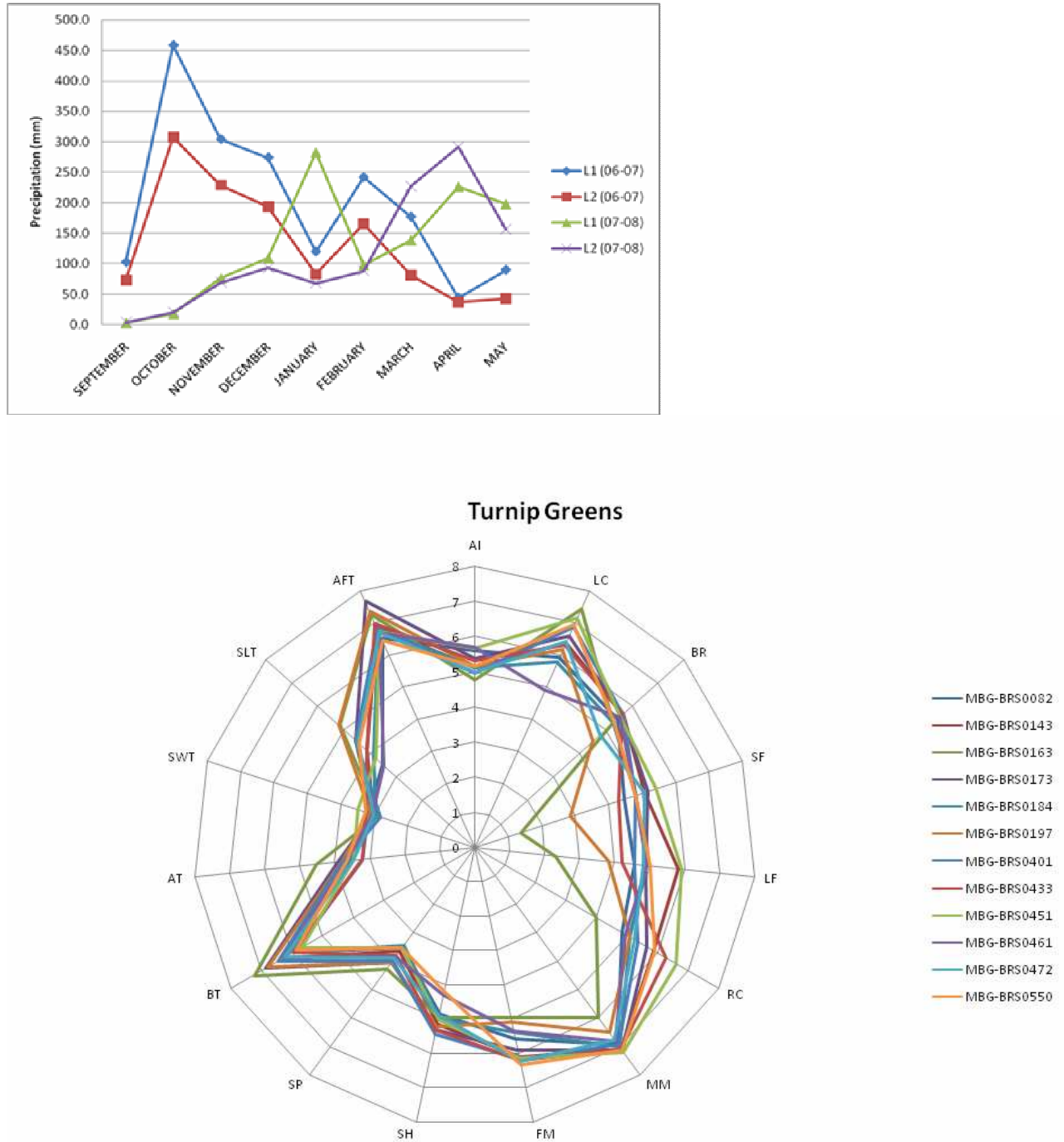